\title{
MPPT Pada Sistem PV Menggunakan Algoritma Firefly dan Modified $P \& O$ dengan Konverter Hybrid Cuk terkoneksi ke Grid Satu Phasa di Bawah Kondisi Partial Shaded
}

\author{
Dhuhari Chalis Bani, Margo Pujiantara, dan Heri Suryoatmojo \\ Jurusan Teknik Elektro, Fakultas Teknologi Industri, Institut Teknologi Sepuluh Nopember (ITS) \\ Jl. Arief Rahman Hakim, Surabaya 60111 \\ E-mail: dhuhari12@mhs.ee.its.ac.id ; margo@ee.its.ac.id ; suryomgt@ee.its.ac.id
}

\begin{abstract}
Abstrak- Photovoltaic (PV) merupakan sumber energi terbarukan yang paling banyak dijumpai di alam serta merupakn energi alternatif yang sangat pesat perkembangannya. Untuk mengahasilkan daya, sebuah PV dipengaruhi sebuah nilai intensitas cahaya matahari yang mengenainya. Sebuah sistem PV membutuhkan sebuah kontrol yang bertujuan untuk meningkatkan efisien daya PV tersebut. Kontrol ini adalah Maximum Power Point Tracking (MPPT) yang dapat mengoptimalkan daya yang dihasilkan oleh PV. Sebuah PV hanya menghasilkan nilai tegangan yang rendah, untuk itu perlu menggunakan koverter DC-DC step up untuk menaikan rasio tegangan DC tadi. Untuk mengoptimalkan sistem ini, diperlukan sebuah konverter yang efisien dan dapat menghasilkan rasio konversi tegangan yang tinggi. Pada penelitian menggunakan firefly algoritm (FFA) dan modified perturb and observe (P\&O) sebagai MPPT untuk mendapatkan nilai daya optimal pada keluaran PV. Konverter DC-DC yang digunakan adalah hybrid cuk converter boost mode yang memiliki rasio tegangan yang tinggi. Dari DC-link kemudian masuk ke inverter (VSI) yang diinterkoneksi dengan grid menggunakan current control. Hasil analisis simulasi menunjukan bahwa FFA dan P\&O mampu menghasilkan daya PV yang optimum dengan riak yang kecil dan konverter hybrid cuk converter boost mode dapat menghasilkan rasio tegangan yang lebih besar dibandingkan konverter cuk biasa.
\end{abstract}

Kata Kunci - PV, MPPT FFA, MPPT P\&O, Hybrid Cuk Converter, DC-Link, Inverter Grid Connected

\section{PENDAHULUAN}

B ertumbuhnya permintaan energi dan naiknya harga bahan bakar fosil memicu untuk terus dilakukan penelitian tentang peningkatan efisiensi energi terbarukan, terutama sistem PV. Dimana PV adalah alat konversi energi dari cahaya matahari menjadi listrik yang memiliki potensi besar di Indonesia tapi masih memiliki efisiensi yang rendah. Untuk meningkatkan efisien sistem PV dapat dioptimalisasikan pada MPPT dan konverter DC-DC nya.

MPPT atau Maximum Power Point Tracker merupakan kontroler yang memiliki algoritma tertentu untuk mencari nilai daya maksimum pada PV. Sudah banyak algoritma yang digunakan sebagai MPPT seperti P\&O, firefly, fuzzy control, RCC dll. Misalnya algoritma $\mathrm{P} \& \mathrm{O}$ yang memiliki keunggulan pada singkatnya waktu untuk mencapai konvergen, tapi terdapat riak yang besar pada daya PV yang dihasilkan. Selain itu algoritma ini juga tidak dapat mengatasi PV yang berada di bawah kondisi partial shaded [1]. Tidak hanya P\&O yang memiliki kekurangan, begitu juga metode firefly. Algoritma firefly memang bisa dimanfaatkan untuk PV yang berada di bawah kondisi partial shaded, tapi memiliki waktu konvergen yang lebih lama dari algoritma P\&O. Oleh karena ini diajukan sebuah penggabungan antara $\mathrm{P} \& \mathrm{O}$ dan firefly menjadi sebuah algoritma yang dapat menyelesaikan partial shaded pada PV dengan waktu konvergen yang lebih cepat.

Tidak hanya dari sisi MPPT, tapi sistem PV juga bisa dioptimalkan dengan pemilihan konverter DC-DC yang tepat. Selain digunakan untuk menunjang kerja MPPT, konverter DC-DC juga digunakan untuk menaikan atau menurunkan tegangan dari nilai tegangan PV menjadi nilai yang kita inginkan. Konverter DC-DC memiliki banyak jenis, dari yang menaikan tegangan saja atau menurunkan saja, hingga konverter DC-DC yang bisa menaikan atau menurunkan tegangan. Sama halnya sebuah algoritma MPPT, setiap jenis konverter juga memiliki kelebihan dan kekurangan masingmasing. Misalkan sebuah konverter cuk yang memiliki efisiensi yang baik karena dapat meredam osilasi yang dihasilkan dari algoritma $\mathrm{P} \& \mathrm{O}$. Tapi, konverter cuk memiliki kekurangan karena membutuhkan duty ratio yang tinggi untuk mendapatkan konversi tegangan yang tinggi dan menahan osilasi tadi. Menangani permasalahan ini, maka digunakanlah sebuah konverter hybrid cuk converter dengan mode meningkatkan tegangan, sehingga mendapatkan konversi tegangan yang lebih tinggi dengan duty ratio yang lebih rendah, tapi tetap dapat meredam osilasi karena MPPT.

\section{PV TERHUBUNG JARINGAN LISTRIK}

Perancangan dan pemodelan sistem dibuat dengan menggunakan SIMULINK/MATLAB. Pemodelan ini terdiri dari PV dengan Partial Shaded Condition, Hybrid Cuk Converter Boost Mode, Single Phase Inverter, filter LC dan jaringan listrik satu phasa. 


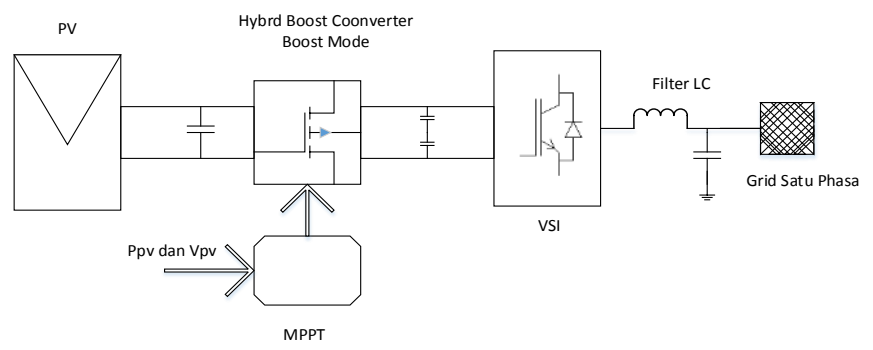

Gambar 1. Skema konfigurasi sistem PV trekoneksi grid

\section{PEMODELAN DAN KONTROL}

Pemodelan dan kontrol MPPT FFA dan P\&O untuk konverter hybrid cuk boost mode pada kedua sumber PV diuraikan berikut ini:

\section{A. Model Photovoltaic (PV)}

Rangkaian ekivalen sel surya dapat direpresentasikan sebagai sumber arus ideal, dioda, resistansi paralel dan resistansi seri. Arus searah yang dihasilkan dari sumber arus ideal adalah sebanding dengan iradiasi cahaya yang diterima sel surya. Resistansi seri dan paralel merepresentasikan nilai drop tegangan sepanjang sampai kontak terminal luar dan arus bocor sepanjang jalur sel .

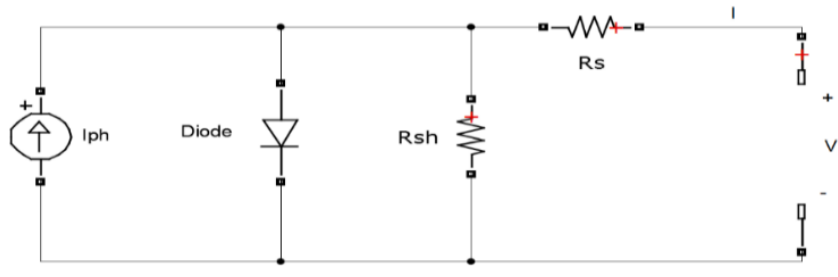

Gambar 2. Rangkaian ekivalen sel PV

Arus output yang disalurkan ke beban dari panel PV dirumuskan persamaan berikut:

$I=I_{S C}-I_{O}\left(e^{\frac{q\left(V+I \times R_{S}\right)}{K \times T \times A}}-1\right)-\frac{V+I \times R_{S}}{R_{S h}}$

Dimana I adalah arus output dari panel PV (A), V adalah tegangan terminal PV yang diperoleh dari jumlah seri sel PV $(\mathrm{V}), \mathrm{I}_{\mathrm{ph}}$ adalah arus sumber panel PV dari iradiasi cahaya (A), $\mathrm{T}$ adalah suhu kerja sel $\left({ }^{\circ} \mathrm{K}\right), \mathrm{I}_{\mathrm{o}}$ adalah arus saturasi dioda $(\mathrm{A})$, $\mathrm{A}$ adalah faktor kualitas dioda $(\mathrm{A}=1 \sim 2)$, $\mathrm{q}$ adalah konstanta muatan elektron $\left(1,6 \times 10^{-19} \mathrm{C}\right)$ dan $\mathrm{K}$ adalah konstanta Boltzman $\left(1,38 \times 10^{-23} \mathrm{~J} /{ }^{\circ} \mathrm{K}\right)$.

Arus $\mathrm{I}_{\mathrm{pv}}$ merupakan arus yang dihasilkan dari konversi cahaya yang dirumuskan:

$I_{p h}=\left(I_{s c}+K_{1}\left(T-T_{r e f}\right)\right) \frac{G}{G_{o}}$

Dimana $\mathrm{I}_{\mathrm{sc}}$ adalah arus short circuit pada kondisi standar $\left(25^{\circ} \mathrm{C}, 1.000 \mathrm{~W} / \mathrm{m}^{2}\right), \mathrm{K}_{1}$ adalah koefisien suhu sel, $\mathrm{G}$ dan Go adalah iradiasi serta referensi iradiasi $\left(1.000 \mathrm{~W} / \mathrm{m}^{2}\right)$.

Panel PV yang digunakan adalah merk Canadian Solar CS5P-220M berdaya puncak 200 Wp sebanyak 6 buah. Penelitian ini menggunakan konfigurasi sistem array PV yang dibentuk dari 2 seri dan 3 paralel panel PV sehingga berdaya
$1.2 \mathrm{kWp}$. Datasheet panel PV ditunjukkan pada tabel 1 berikut:

Tabel 1

Canadian Solar CS5P-200M

\begin{tabular}{l|c}
\hline \multicolumn{1}{c|}{ Parameter } & Nilai \\
\hline Number of Cells & 76 \\
Maximum power & $220 \mathrm{~W}$ \\
Maximum power voltage (Vmp) & $37,46 \mathrm{~V}$ \\
Maximum power current (Imp) & $5,3 \mathrm{~A}$ \\
Open-circuit Voltage (Voc) & $45,8 \mathrm{~V}$ \\
Short-circuit current(Isc) & $5,63 \mathrm{~V}$ \\
Light Intensity & $1 \mathrm{~kW} / \mathrm{m}^{2}$ \\
Temperature & $25^{\circ} \mathrm{C}$ \\
\hline \hline
\end{tabular}

Daya sistem panel surya diperoleh dari hasil perkalian tegangan dan arus PV. Maksimum daya dari panel PV terjadi saat perkalian tegangan (V) dan arus (I) yang maksimum. Titik ini dikenal dengan Maximum Power Point (MPP) dan dapat dilihat pada Gambar 3.

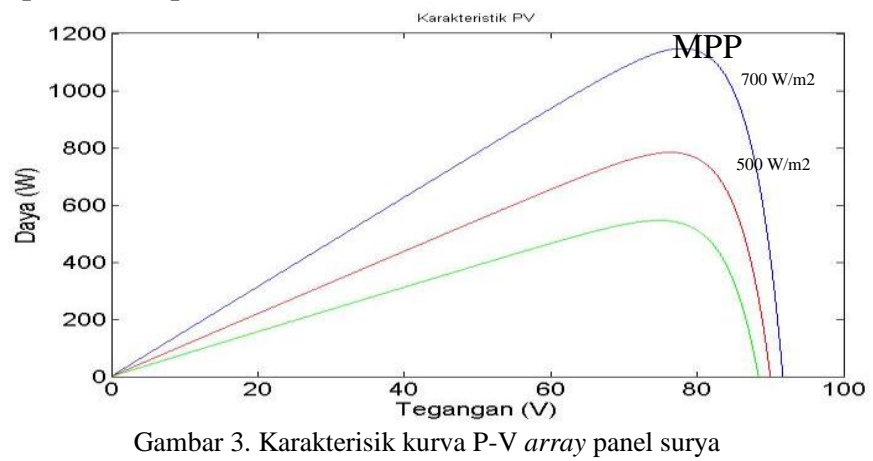

\section{B. Konverter Hybrid Cuk Boost Mode}

Topologi rangkaian konverter Hybrid Cuk Boost Mode terdiri dari dua buah induktor, dua buah kapasitor, dua buah dioda, dan satu jenis saklar semikonduktor seperti yang ditunjukkan pada gambar 6 berikut.

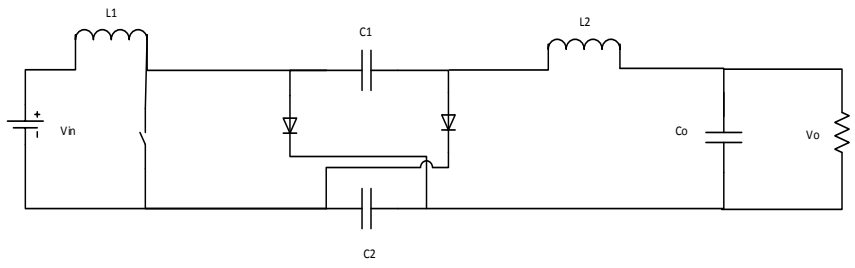

Gambar 4. Skema rangkaian Hybrid Cuk Boost Mode

Rasio tegangan input-output yang dihasilkan dirumuskan:

$\frac{V_{o}}{V_{\text {in }}}=\frac{1+D}{1-D}$

Parameter komponen rangkaian konverter Hybrid Cuk Boost Mode yang digunakan pada panel PV menyesuaikan terhadap kapasitas daya dan rentang nilai tegangan input operasi dari kedua sumber tersebut. Dengan menggunakan persamaan (4), (5), (6) dan, (7) berikut [1],

$$
\begin{aligned}
& L_{1 \min }=\frac{D T(1+D)^{2}}{R_{o}(1-D)^{2}} \\
& L_{2 \min }=\frac{(2+D)(1-D) R_{O} T}{(1+D)^{2}}
\end{aligned}
$$




$$
\begin{aligned}
& C=\frac{V_{o}^{2}(1-D) T D}{R_{o} V_{i n} \Delta V_{C}} \\
& C_{o}=\frac{V_{o} D T}{\Delta V_{o} R_{O}}
\end{aligned}
$$

Dengan menggunakan persamaan diatas maka diperoleh parameter induktansi dan kapasitansi pada konverter hybrid cuk boost mode sebagai berikut:

Tabel 2

Parameter HGICB pada panel PV

\begin{tabular}{l|c}
\hline \multicolumn{1}{c}{ Parameter } & Nilai \\
\hline $\mathrm{L}_{1}$ dan $\mathrm{L}_{2}$ & $6.8 \mathrm{mH}$ dan $0.0658 \mathrm{H}$ \\
$\mathrm{C}_{1}$ dan $\mathrm{C}_{2}$ & $45.9 \mu \mathrm{F}$ dan $45.9 \mu \mathrm{F}$ \\
$\mathrm{C}_{\mathrm{o}}$ & $20.8 \mu \mathrm{F}$ \\
Tegangan input, Vin & $74.92 \mathrm{~V}$ \\
Frekuensi switching, fs & $20 \mathrm{kHz}$ \\
\hline \hline
\end{tabular}

\section{Kontrol MPPT FFA dan $P \& O$ pada $P V$}

Pada penelitian ini digunakan kontrol MPPT menggunakan FFA dan modified P\&O. Kontrol MPPT digunakan untuk mencari titik daya maksimum pada setiap nilai intensitas cahaya matahari. Keluaran dari kontrol MPPT adalah berupa duty cycle untuk mengatur pensaklaran hybrid cuk converter boost mode.

\section{MPPT FFA}

Algoritma firefly terinspirasi oleh pergerakan kunangkunang. Pada algoritma ini, ada 3 asumsi yang digunakan:

1) semua kunang-kunang adalah unisex, sehingga kunangkunang tertarik dengan kunang-kunang yang lain tidak memperhitungkan jenis kelamin kunang-kunang tersebut.

2) Ketertarikan antar kunang-kunang berdasarkan seberapa terang dari kunang-kunang tersebut. Kunang-kunang yang lebih redup maka akan tertarik dan berpindah mendekati kunang-kunang yang lebih terang.

3) terang redupnya seekor kunang-kunang ditentukan dalam semuah fungsi objektif.

Misalkan ada 2 ekor kunang-kunang, $\mathrm{p}$ dan $\mathrm{q}$, yang memiliki jarak $\mathrm{r}_{\mathrm{pq}}$ dan masing-masing posisi kunang tersebut adalah $\mathrm{X}_{\mathrm{P}}$ dan $\mathrm{X}_{\mathrm{q}}$ yang merepersentasikan duty cycle pada MPPT.

$r_{p q}=\left\|X_{p}-X_{q}\right\|$

$\beta(r)=\beta_{O} e^{-\gamma\left(r_{p q}\right)^{n}}, \quad n \geq 1$

Dimana $\beta_{O}$ adalah initial derajat ketertarikan, bisanyan bernilai 1 .

Asumsikan bahwa kunang-kunang $\mathrm{p}$ lebih redup dari pada kunang-kunang maka, posisi baru akan diperoleh oleh kunang-kunang q sesuai dengan persmaan berikut:

$X_{p}^{t+1}=X_{p}^{t}+\beta(r)\left(X_{p}-X_{q}\right)+\alpha\left(\right.$ rand $\left.-\frac{1}{2}\right)$

Rand di dalam persamaan adalah nilai acak yang terdistribusi dari 0 dan 1 . Besarnya nilai membuat pergerakan untuk mencari tempat yang jauh dan apabila kecil maka cendrung mencari pada pencarian lokal.

\section{MPPT Modified $P \& O$}

Algoritma $\mathrm{P} \& \mathrm{O}$ bekerja berdasarkan observasi pada daya keluaran PV dan memberi gangguan berupa penambahan atau pengurangan daya dengan megubah nilai duty cycle.

\section{MPPT FFA dan Modified $P \& O$}

Pada tugas akhir ini algoritma MPPT yang digunakan adalah algoritma gabungan antara Firefly Algorithm (FFA) dan Perturb and Observe Algorithm ( $\mathrm{P} \& \mathrm{O})$. Kedua algortima ini memiliki kelebihan dan kekurangan masing-masing. FFA memiliki keunggulan ketika berada dalam PSC tapi memiliki waktu konvergen yang lebih lama dari pada P\&O. Disisi lain, $\mathrm{P} \& \mathrm{O}$ memiliki waktu konvergensi yang cepat tapi memiliki kemungkinan yang lebih besar untuk terjebak pada titik Local Maximum Power (LMP) ketika terjadi kondisi PSC [2].

Untuk itu dilakukan penggabuangan kedua algortima ini untuk menghasilkan algoritma yang lebih baik. Pertama kali MPPT ini bekerja, MPPT ini menggunakan algoritma FFA untuk menghindari LMP pada PSC. Kemudian, algoritma akan beralih menjadi $\mathrm{P} \& \mathrm{O}$ ketika rentang antara kunang-kunang (duty cycle) awal dan akhir dibawah sudah cukup kecil (sekitar $0.5)$ [3].

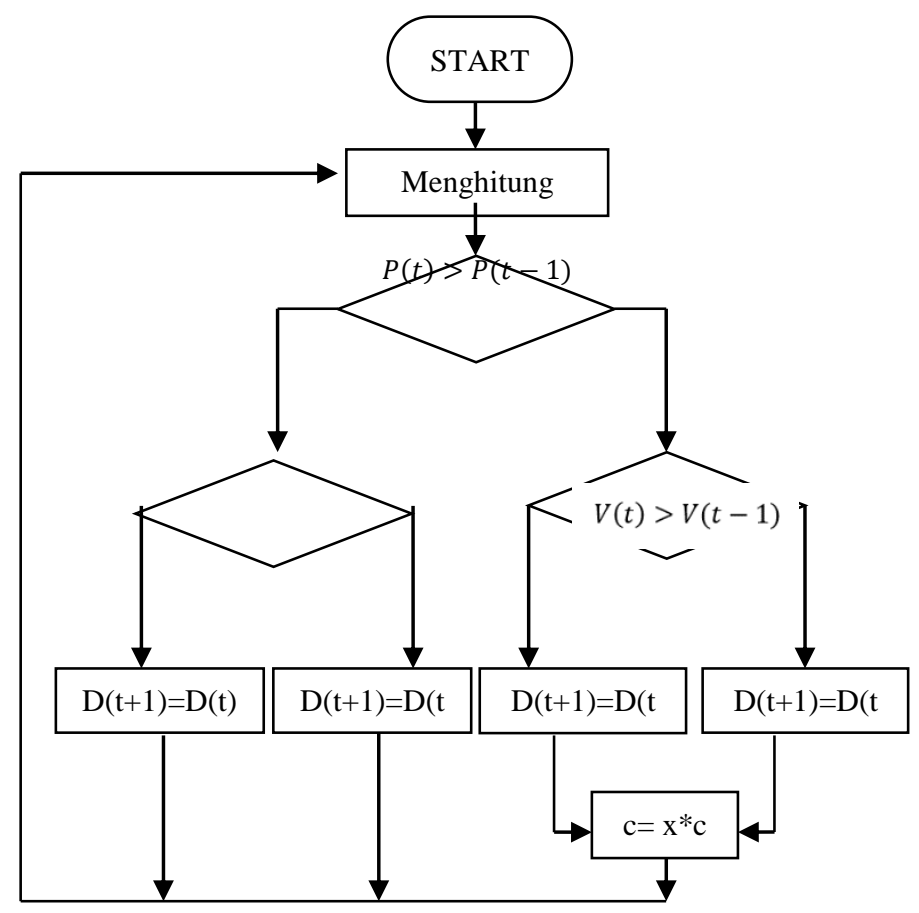

Gambar 5. Diagram alur metode modified P\&O 


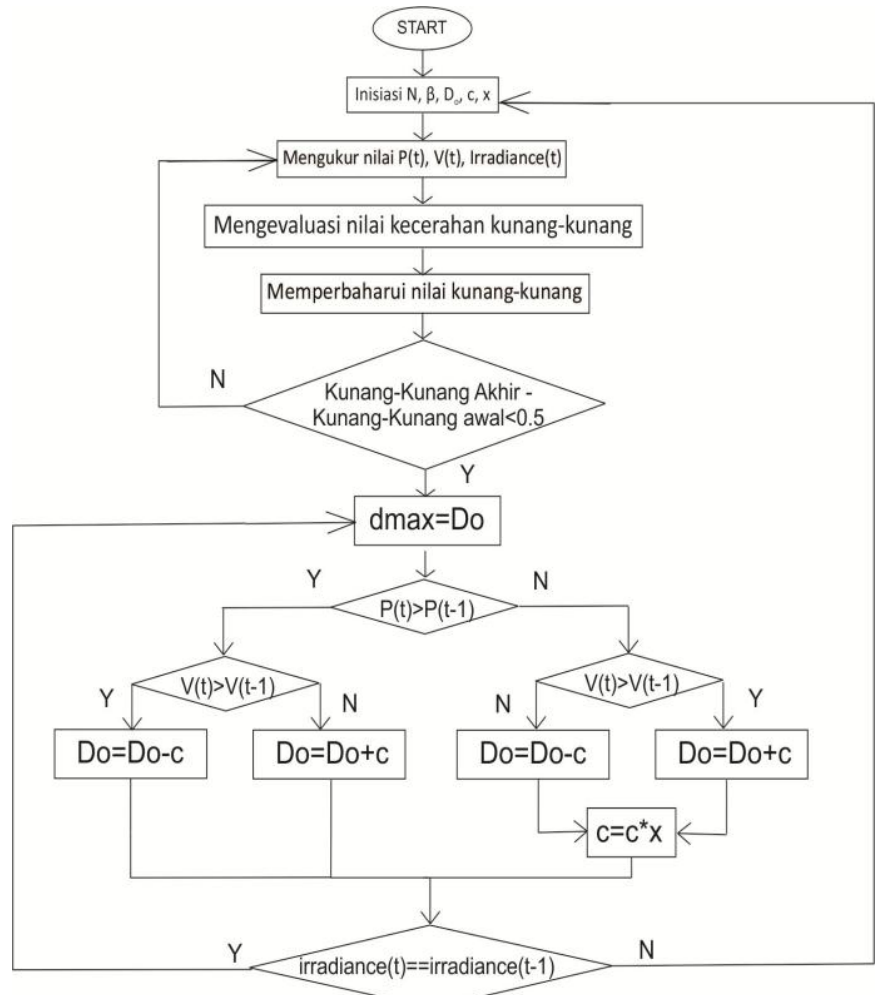

Gambar 6. Diagram alur metode modified P\&O

\section{Model Inverter (VSI) Satu Phasa Terkoneksi Grid}

Untuk mengalirkan daya aktif dari sisi DC ke sisi AC, tegangan DC harus lebih tinggi dari pada nilai tegangan grid. Karena tegangan grid satu phasa adalah $220 \sqrt{2} \mathrm{~V}$, maka nilai tegangan $400 \mathrm{~V}$ pada DC-link sudah cukup untuk memenuhi syarat [4].

Pada tugas akhir ini menggunakan sebuah double-loop control untuk menjaga nilai tegangan DC tetap konstan dan daya aktif, hal ini dikenal sebagai outer voltage loop dan inner current loop control.

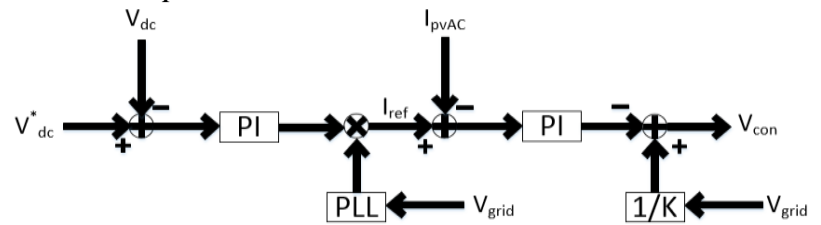

Gambar 7. Double-loop conttrol strategy secara umum

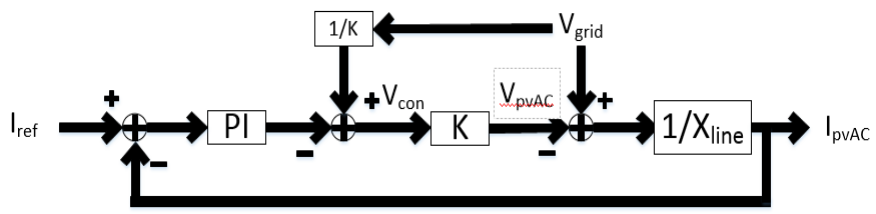

Gambar 8. Double-loop conttrol strategy

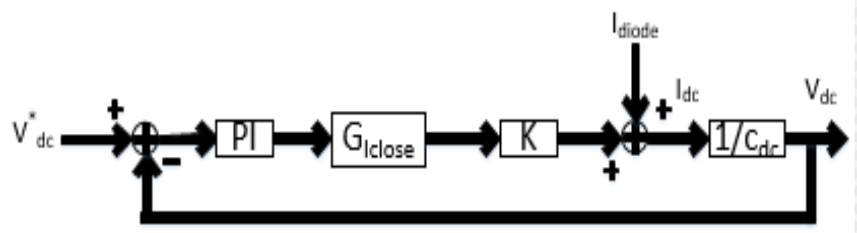

Tabel 3

Parameter inverter (VSI)

\begin{tabular}{l|c}
\hline \hline \multicolumn{1}{c|}{ Parameter } & Nilai \\
\hline Frekuensi switching & $10 \mathrm{kHz}$ \\
Kapasitor DC-link & $24 \mu \mathrm{F} \times 2$ \\
Tegangan DC-link $(\mathrm{Vdc})$ & $650 \mathrm{~V}$ \\
Tegangan AC $\left(V_{\text {grid }}\right)$ & $380 \mathrm{~V}$ \\
Frekuensi grid & $50 \mathrm{~Hz}$ \\
Filter LC & $17,8 \mu \mathrm{H} \mathrm{dan} 5 \mu \mathrm{F}$ \\
\hline \hline
\end{tabular}

\section{ANALISIS PENGUJIAN SISTEM}

Pada sub bab ini akan dilakukan pengujian terhadap PV. Pengujian dilakukan dengan beberapa perubahan intensitas $\left(1000 \mathrm{~W} / \mathrm{m}^{2}, \quad 700 \mathrm{~W} / \mathrm{m}^{2}, 500 \mathrm{~W} / \mathrm{m}^{2}\right)$ dan kondisi PSC. Perubahan intensitas dan kondisi PSC bertujuan untuk menguji seberapa efisien dari sebuah algoritma MPPT yang digunakan dalam mencari titik daya maksimum PV. Ada dua algoritma MPPT yang akan dibandingkan pada bab ini, yakni algoritma gabungan FFA dan $\mathrm{P} \& \mathrm{O}$ dengan algoritma $\mathrm{P} \& \mathrm{O}$.

Selain itu, pada bab ini juga akan dilakukan perbandingan konverter DC-DC yang digunakan sebagai media untuk menggiring titik daya PV menuju titik daya maksimum. Pada pengujian ini akan dilakukan perbandingan antara konverter hybrid cuk dengan konverter cuk [5].

\section{A. Performansi MPPT}

Kurva intensitas cahaya dalam pengujian ditunjukan oleh gambar 10. Masing-msing nilai intensitas cahaya menghasilkan daya maksimum yang berbeda-beda. Gambar 11 dan gambar12 memperlihatkan nilai daya maksimum dari masing-masing nilai intensitas cahaya.

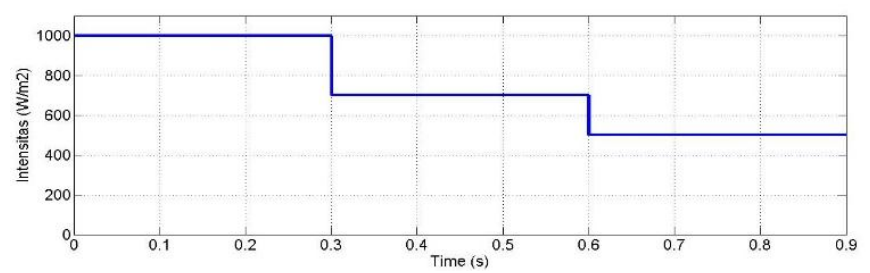

Gambar 10. Grafik perubahan intensitas

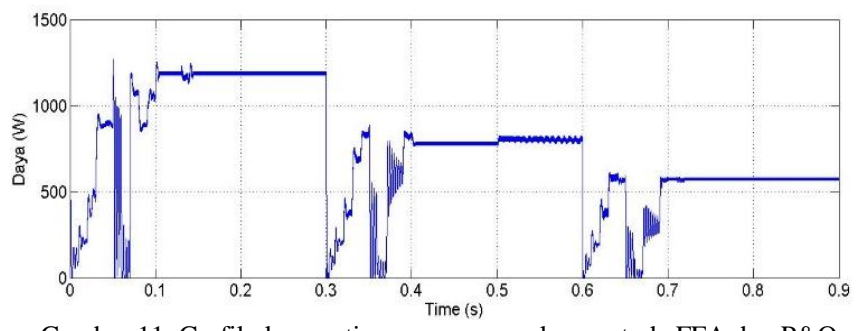

Gambar 11. Grafik daya optimum menggunakan metode FFA dan P\&O

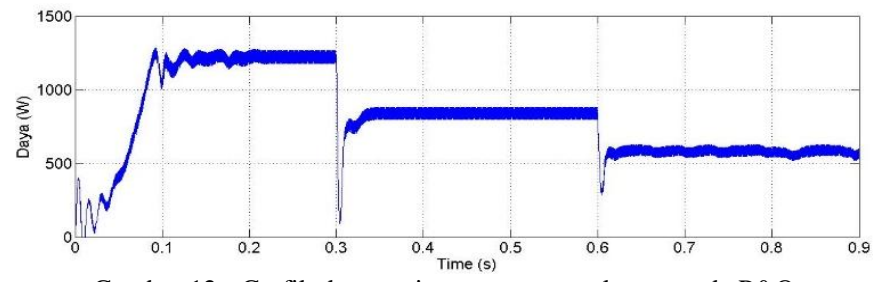

Gambar 12. Grafik daya optimum menggunakan metode $\mathrm{P} \& \mathrm{O}$ 
Tabel 4

Hasil metode FFA dan P\&O

\begin{tabular}{cccc}
\hline \hline Iradiasi $\left(\mathrm{W} / \mathrm{m}^{2}\right)$ & $\begin{array}{c}\text { Daya Referensi } \\
(\mathrm{W})\end{array}$ & $\begin{array}{c}\text { Daya Aktual } \\
(\mathrm{W})\end{array}$ & $\begin{array}{c}\text { Error Daya } \\
(\%)\end{array}$ \\
\hline 1000 & 1200 & 1185 & 1.25 \\
700 & 842 & 800 & 4.9 \\
500 & 584 & 575 & 1.5 \\
\hline \hline \multicolumn{4}{c}{ Tabel 5 } \\
\multicolumn{4}{c}{} \\
\hline \hline Iradiasi & Hasil metode P\&O \\
$\left(\mathrm{W} / \mathrm{m}^{2}\right)$ & Deferensi & Daya Aktual & Error \\
\multicolumn{4}{c}{$(\mathrm{W})$} \\
\hline 1000 & $(\mathrm{~W})$ & Daya \\
700 & 1200 & $1 \%)$ \\
500 & 842 & 805 & 0 \\
\hline \hline
\end{tabular}

Dari table 4 dan tabel 5 dapat dilihat bahwa dengan menggunakan metode gabungan menghasilkan error daya (selisih daya referensi terhadap daya aktual) dan time convergent yang sedikit lebih besar dibandingkan dengan menggunakan metode $\mathrm{P} \& O$. Disisi lain dengan menggunakan metode gabung menghasilkan riak daya jauh lebih sedikit dari pada dengan menggunakan metode $\mathrm{P} \& \mathrm{O}$.

Selain perubahan intensistas cahaya secara seragam pada $\mathrm{PV}$, pada kondisi nyata dapat terjadi ketidak seragaman intensitas cahaya matahari yang mengenai PV. Kondisi ini disebut Partial Shaded Condition (PSC). Untuk pengujian dilakukan tiga kasus yang berbeda seperti yang telah disebut pada bab 3. Berikut adalah hasil dari pencarian daya optimum dengan metode gabungan dan metode $\mathrm{P} \& \mathrm{O}$. Dalam hal ini akan dilakukan dari kedua metode tersebut.

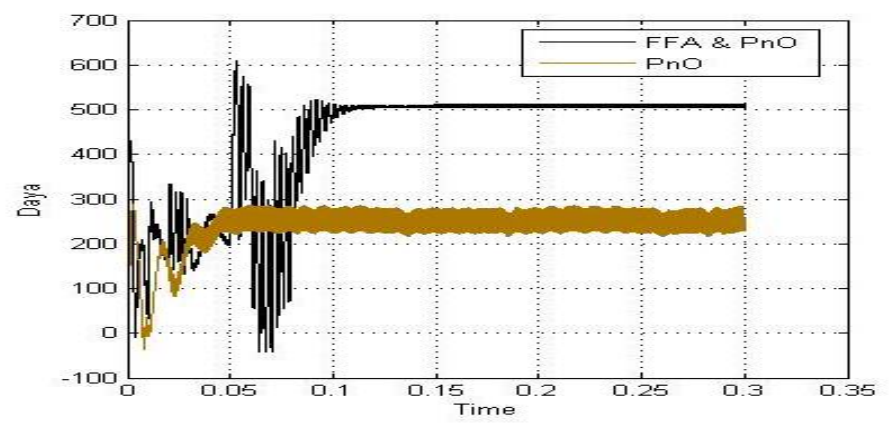

(a)

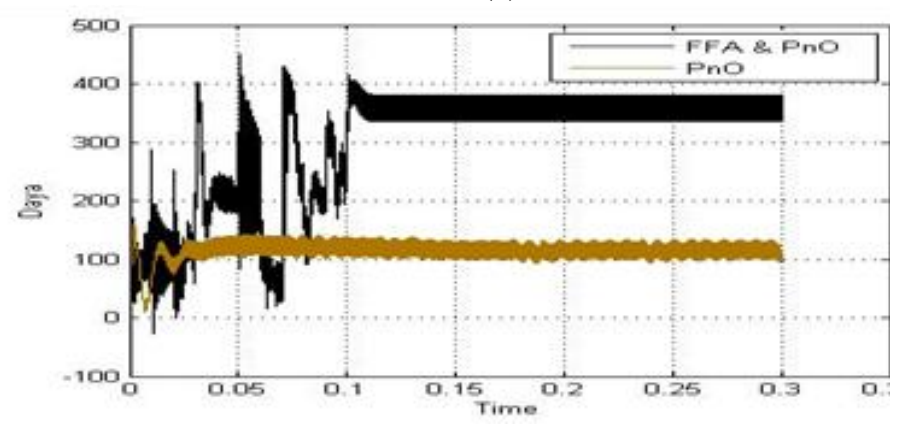

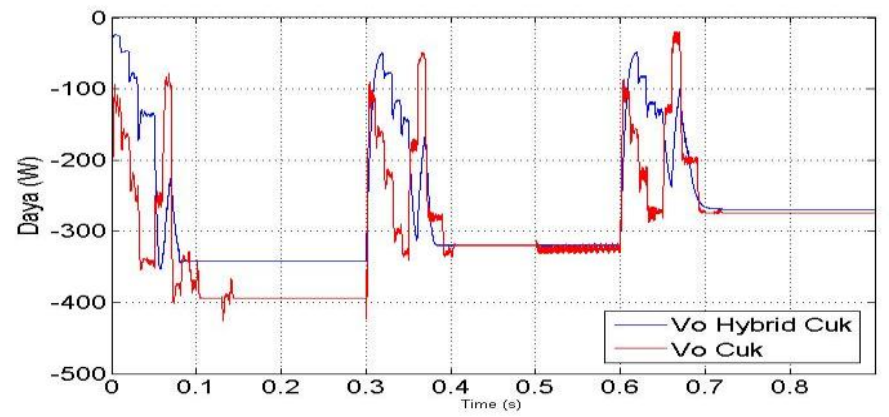

(b)

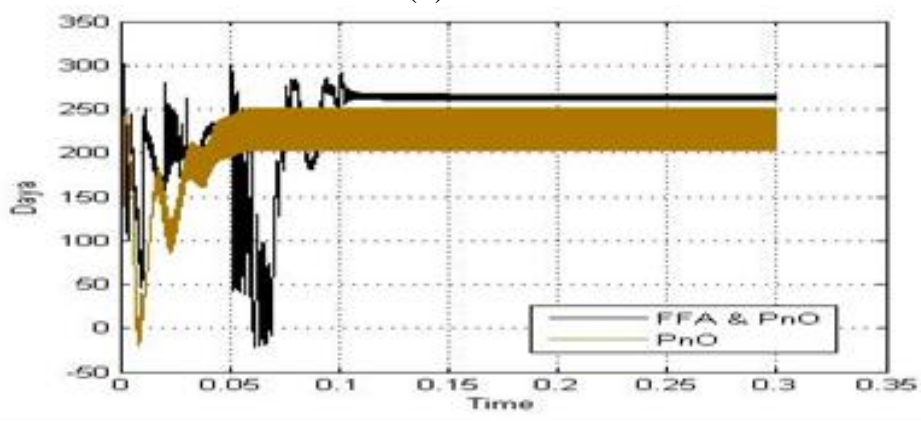

(c)

Gambar 13. Grafik daya optimum pada PSC (a) PSC I (b) PSC II (c) PSC III

Tabel 6

Hasil Daya pada PSC

\begin{tabular}{lcc} 
Kasus & FFA dan PnO $(\mathrm{W})$ & PnO $(\mathrm{W})$ \\
PSC I & 508 & 256 \\
PSC II & 351 & 112 \\
PSC III & 262 & 228 \\
\hline
\end{tabular}

Gambar diatas menunjukan perbandingan antara metode gabungan dan metode $\mathrm{P} \& \mathrm{O}$. Terlihat jelas bahwa metode $\mathrm{P} \& \mathrm{O}$ terjebak pada LMP dari PSC, sedangkan metode gabungan tidak terjebak di LMP. Sehingga dengan metode gabungan diperoleh nilai daya lebih optimum.

\section{B. Analisis Pengujian Konverter}

Pada tugas akhir ini dilakukan perbandingan antara Hybrid Cuk Converter dan Cuk Converter. Perbandingan antara 2 konverter ini ditinjau dari riak tegangan dan error daya konverter.

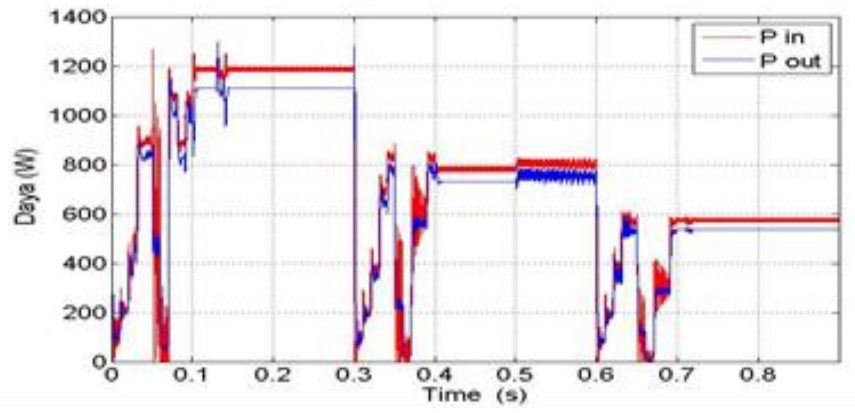

Gambar 13. Grafik daya hybrid cuk converter 

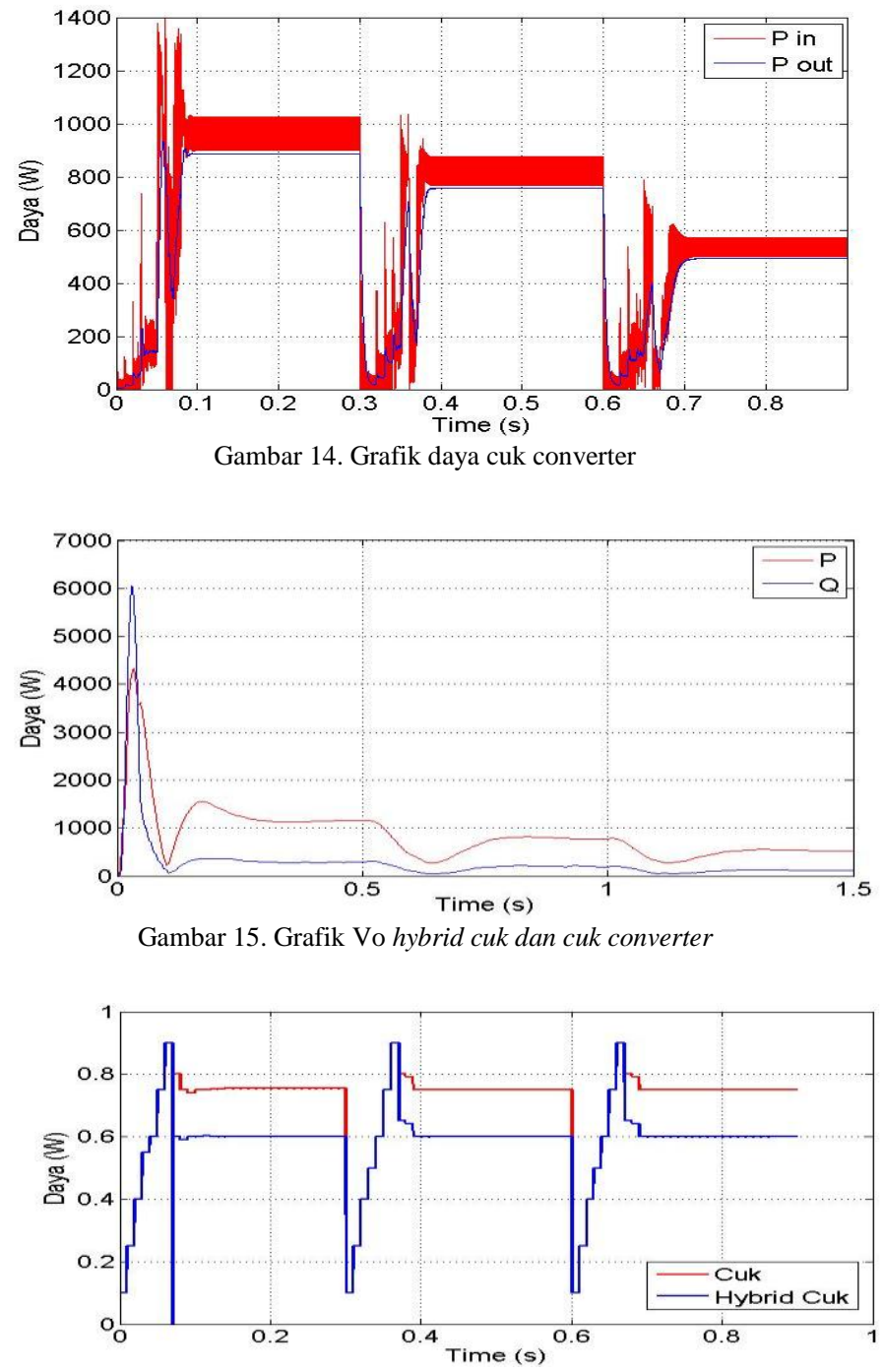

Gambar 16. Grafik duty ratio hybrid cuk dan cuk converter

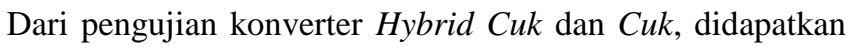
perbedaan error daya yang lebih besar pada konverter cuk. Mengamati osilasi tegangan output dari kedua tidak terlihat perbedaan yang jauh, tetapi terdapat riak yang lebih besar pada konverter cuk dibandingkan dengan konverter hybrid cuk..

Disisi lain, ratio tegangan yang dapat dihasilkan pada konverter hybrid cuk lebih besar dibandingkan konverter cuk dengan duty ratio yang sama. Pada penelitian ini, tegangan keluaran yang dibutuhkan adalah 400 VDC untuk dihubungkan ke grid 220 VAC. Untuk meghasilkan tegangan 400 VDC, konverter hybrid cuk membutuhkan duty ratio sekitar 0.6 sedangkan konverter cuk membutuhkan duty ratio sekitar 0.75 .

\section{Pengujian Inverter Terkoneksi ke Grid}

Pengujian dilakukan dengan cara mengukur daya yang dikirimkan ke beban dan grid. Beban yang digunakan adalah beban resistif sebesar $60 \mathrm{Ohm}$ dengan teganngan sebesar 220 $\mathrm{V}$, sehingga daya yang dibutuhkan oleh beban tersebut adalah $806.6 \mathrm{~W}$.

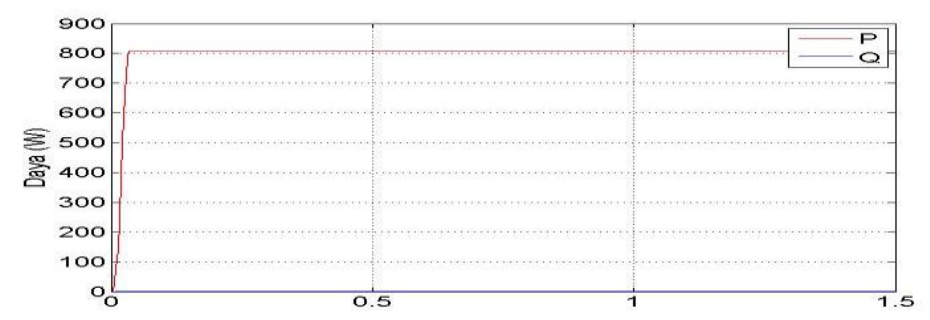

Gambar 17. Grafik Daya aktif dan reaktif beban

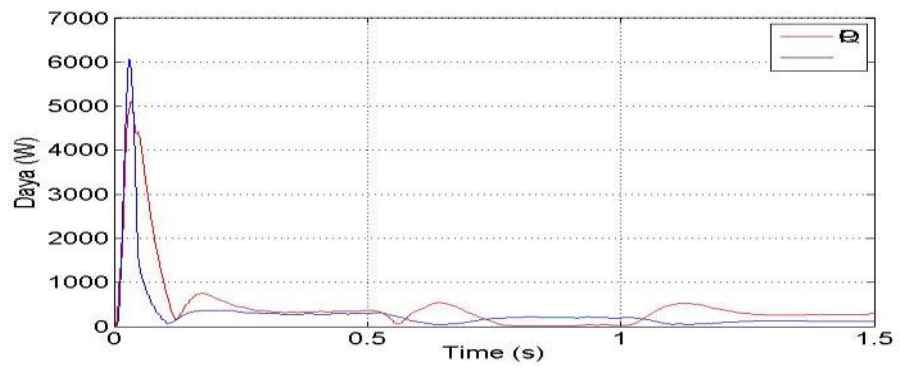

Gambar 18. Grafik Daya aktif dan reaktif inverter

Dari hasil pengujian sebelumnya bahwa pada intensitas $1000 \mathrm{~W} / \mathrm{m}^{2}$, sistem PV menghasilkan $1180 \mathrm{~W}$ dengan mengunakan MPPT FFA dan P\&O dan konverter Hybrid cuk. Setelah melewati inverter satu phasa, daya dari sistem PV mengalami penurunan daya menjadi $1165 \mathrm{~W}$ (turun sekitar $1.2 \%$ ). Penurunan daya ini disebabkan parameter $\mathrm{R}$ (hambatan) yang ada pada komponen switching.

Ketika daya yang yang dihasilkan PV tidak mencukupi daya yang dibutuhkan oleh beban karena perubahan intensitas cahaya, maka grid akan menyuplai daya kebeban. Perubaan aliran daya pada grid (menyuplai atau disuplai) dapat dilihat dari perbedaan phasa antara arus grid terhadap tegangan grid.

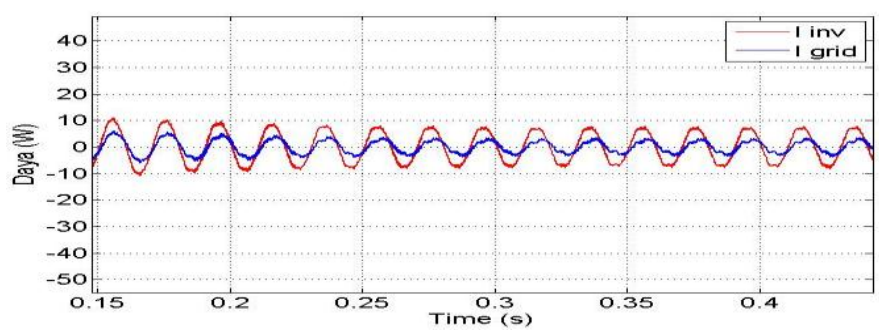

(a)

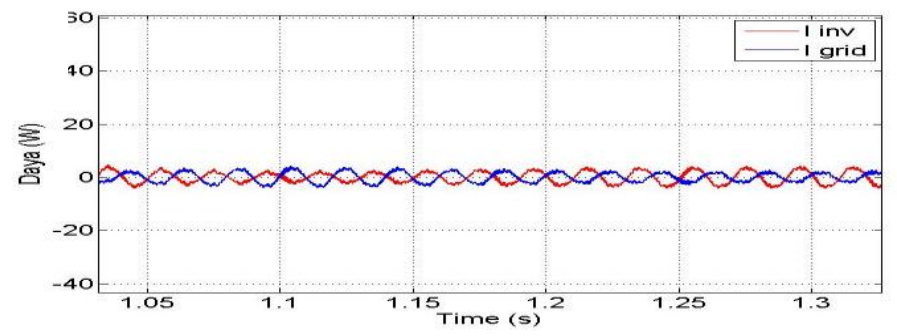

(b)

Gambar 19. Perbedaan Phasa antara arus grid dan arus inverter 


\section{KESIMPULAN}

1. MPPT dengan metode FFA dan P\&O menghasilkan riak yang lebih kecil dibandingkan dengan metode P\&O saja. Metode ini menghasilkan error daya yang sedikit lebih besar dibandingkan dengan metode $\mathrm{P} \& \mathrm{O}$.

2. Hybrid cuk converter menghasilkan daya yang lebih optimum dari pada cuk converter.

3. Metode FFA dan P\&O menghasilkan daya yang lebih optimum dibandingkan dengan metode $\mathrm{P} \& \mathrm{O}$ saja.

4. Terdapat rugi-rugi pada saklar sehingga terdapat sedikit perbedaan daya masukan dan daya keluaran konverter DCDC, turun sekitar $1.27 \%$.

5. Untuk menghasilkan ratio tegangan yang sama, hybrid cuk converter membutuhkan duty ratio yang lebih kecil dari pada cuk converter.

\section{DAFTAR PUSTAKA}

[1] R, Sankarganesh. "Maximum Power Point Tracking in PV System using Intelligence based P\&O Technique and Hybrid Cuk Converter", International Conference in Emerging Trends in Science, Engineering and Technology, 2012

[2] Safarudin, Mahfudz, "Combining Simplified Firefly and Modified $P \& O$ Algorithm for Maximum Power Point Tracking of Potovoltaic System Under Partial Shading Condition", International Seminar on Intelligent Technology and Its Application, 2015.

[3] Kurnia M. Pebriningtyas. "Penelusuran Daya Maksimum Pada Panel Photovoltaic Menggunakan Kontrol Logika Fuzzy Di Kota Surabaya". Jurnal Teknik POMITS Institut Teknologi Sepuluh Nopember. Suarabaya, 2013

[4] Rahim, Nasrudin ABD, "Hysterysis Current Control and Sensorless MPPT for Grid-Connected Photovoltaic Systems", IEEE1-4244-07559/07,2007

[5] Ahmed Refaat, Ahmed Kalas and Ahmed Daoud, "A Control Methodology of Three Phase Grid Connected PV System", Departmen of Electrical power Engineering Port Said University, Egypt, 2014 